\title{
VOLTAGE COMPENSATION USING ARTIFICIAL NEURAL NETWORK: A CASE STUDY OF RUMUOLA DISTRIBUTION NETWORK
}

\author{
R. Uhunmwangho ${ }^{1}$, E. Omorogiuwa ${ }^{2,}$ and G. Offor ${ }^{3}$

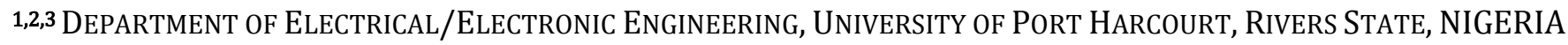 \\ E-mail addresses: ${ }^{1}$ eseosa.omorogiuwa@uniport.edu.ng; ${ }^{2}$ tripodeng@yahoo.com, ${ }^{3}$ goodnessoffor@gmail.com
}

\begin{abstract}
A study of hourly voltage log taken over a period of six months from Rumuola Distribution network Port Harcourt, Rivers State indicates that power quality problems prevalent in the Network are undervoltage/voltage sags and overvoltage/voltage swells. This paper aims at addressing these power quality problems in the distribution network using artificial neural network (ANN) controller based dynamic voltage restorer (DVR). The artificial neural networks controller engaged to controlling the dynamic voltage restorer were trained with input and output data of proportional integral (PI) controller and of unit amplitude generator obtained during simulation. All simulations and modeling were carried out in MathLab/Simulink. Proposed dynamic voltage restorer was tested with replicated model of Rumuola substation by simulating with sample of average voltage for Omerelu, Waterlines, Rumuola, Shell Industrial and Barracks feeders. Simulation results showed that DVR is effective in compensating for under-voltage and over-voltage in Rumuola Distribution network Port Harcourt, Rivers State.
\end{abstract}

Keywords: Rumuola distribution, power quality, ANN, Mathlab/Simulink, Dynamic voltage restorer

\section{INTRODUCTION}

Until early $20^{\text {th }}$ century, the quality of power supply was not considered as important factor in power delivery. Utility companies only focused on achieving a power delivery state with little or no interruption. But with improvement in technology, paving way for development of very sensitive loads, and coupled with customer awareness, increased in electricity demand in homes, offices and industries, and inter-connection of electrical utility into complex grid etc, power system engineers were implored to consider power quality. Power quality as a term, defines a set of electrical boundaries within which a piece of equipment can function as intended without significant loss of performance or life expectancy [1]. It entails delivering electric power with minimal distortions, and therefore, maintaining a near sinusoidal signal waveform at a frequency of $50 \mathrm{~Hz}$ and at required load voltage.

Power Quality problems are manifested in voltage, current or frequency [2]. Examples include: voltage swell and sag, voltage fluctuation, harmonic distortions etc. Aside factors like power system faults, start up and shutdown of heavy equipment, switching operations etc, non-linear loads are identified as major cause of power quality problems [3]. Power quality problems are global issues and exist in distribution systems of several countries of the world, including Nigeria [4], Libya [5], India [6] and Germany [7]. The effects of power quality problems are enormous, ranging from equipment failure to equipment damage which can result in huge financial losses in process and automation industries. In Rumuola distribution system network, under-voltage and overvoltage are identified as major power quality problems [8].

The need to mitigate power quality problems and maintain power of good quality has brought power system engineers, equipment manufacturers, researchers and statutory bodies to a focal point of methodology development. Today, several methods exist to improve the quality of power to sustain the ever increasing applications of sensitive and non-linear loads in distribution network. Conventionally, Synchronous condenser, capacitor banks, static VAR compensators (SVCs), self-commutated VAR compensators etc. are used to control reactive power and improve power factor, though with drawbacks such as instability problems, generation of high transient during connection and disconnection etc. [9]. More recently, Custom power devices such as distribution static compensator (DSTATCOM), unified power quality conditioner (UPQC), dynamic voltage restorer (DVR) etc were found to be improved methods for power quality control. Onohaebi 
and Omorogiuwa [10] considered the relevance of custom devices in tackling power efficiency problems in Nigeria distribution network stating that such devices have been widely used in distribution network of developed countries. However, the performance of custom power devices is dependent on the type of controller employed. Proportional integral (PI), proportional integral differentiators etc are effective but slow in response and perform poorly under parameter variations. Artificial intelligent (AI) controllers such as Artificial Neural Network (ANN), fuzzy logic etc [11] are proposed by researchers as they offer better performance in terms of response time and operation under dynamic loads.

Several authors have researched on mitigating power quality problems in distribution system network using DVR. Harmonics and undervoltage compensation using DVR was studied by Sundarabalan C. K. and Selvi K. [12] using ANN controller based on park's transformation strategy. The ANN controller was trained off-line with data from a proportional integral controller. In another study, Shairul, et al simulated the performance of DVR using PSCAD [13]. Raunak, et al [14] in their study of DVR performance on sag and swell mitigation applied PI controller and unit vector extraction control scheme. In these studies, a simple distribution network composed of two feeders fed from a substation was employed, and voltage sag was simulated by different conditions. The results obtained showed the effectiveness of DVR in under-voltage and over-voltage mitigation [14]. This paper seeks to improve power quality by mitigating under-voltage and over-voltage using ANN based controller model of dynamic voltage restorer (DVR). The distribution system adopted for this study is the Rumuola distribution sub-station (RDS) network, Port Harcourt, Nigeria.

\section{METHODOLOGY}

\subsection{Mathematical formulation}

Mathematical formulae were adopted to design the various components of the DVR system.

\subsection{Software}

Modeling and simulation of DVR and Rumuola Injection station were carried out in MatLab 2013 application.

\subsection{Data collection}

All data used for this paper were collected from Rumuola Injection station at Garden City central Integrated Business Centre, and Rumuodumaya Business Unit, Rivers State, Nigeria.
From Rumuola Injection Station:

- Hourly secondary voltage of the three power transformer located in the station. These were got from the hourly/daily log book in the control room, and analysed by comparing with IEEE 519 recommendations to define the power quality problems in the network.

- $\quad$ Feeder names and nominal voltages, route lengths and average loads. These were received from the business unit, and were used to model the network in MatLab.

From Rumuodumaya Business Unit:

- The schematic diagram of Port Harcourt distribution network. From it, the single-line diagram of the Rumuola Injection station was obtained with capacities of the two sources by which the station is being supplied. The single-line diagram of the Rumuola Injection station was used to draw the simulation diagram in MatLab.

These data were simulated in MatLab 2013 and the results were analysed using waveforms and voltage readings.

\subsection{Rumuola Distribution System}

Rumuola Distribution Sub-station is a part of Port Harcourt distribution network and is fed from Port Harcourt Mains sub transmission station via two $33 \mathrm{kV}$ lines; Refinery line 1 and Rumuola Feeder 3. These feeders have a maximum load capacity of 31.8MW and are taken from two transformers rated 60MVA, $132 / 33 \mathrm{kV}$ each.

Rumuola sub-station has three transformers rated 15MVA, 33/11kV each and eight (8) outgoing load feeders; New GRA, Rumuomoi, Barracks, Bori comp, shell Industrial, Rumuola, Omerelu and Waterlines. Figure 1 shows the single-line diagram of the sub-station with Port Harcourt Mains transmission lines. Table 1 gives the nominal voltage levels, route length and average loads on the sub-station load feeders and the two sources feeding the station. The total average power demand of the station is $32.22 \mathrm{MW}$. The substation operates a load shedding due to the fact that the maximum power demand on the station is $33.22 \mathrm{MW}$

A study of raw data collected over a period of six months indicates that power quality problems prevalent in the network are undervoltage/voltage sags and overvoltage/voltage swells as shown in table 2 . This study aims at mitigating these problems to improve the quality of power distributed by the station using ANN based dynamic voltage restorer. 
PH MAINS

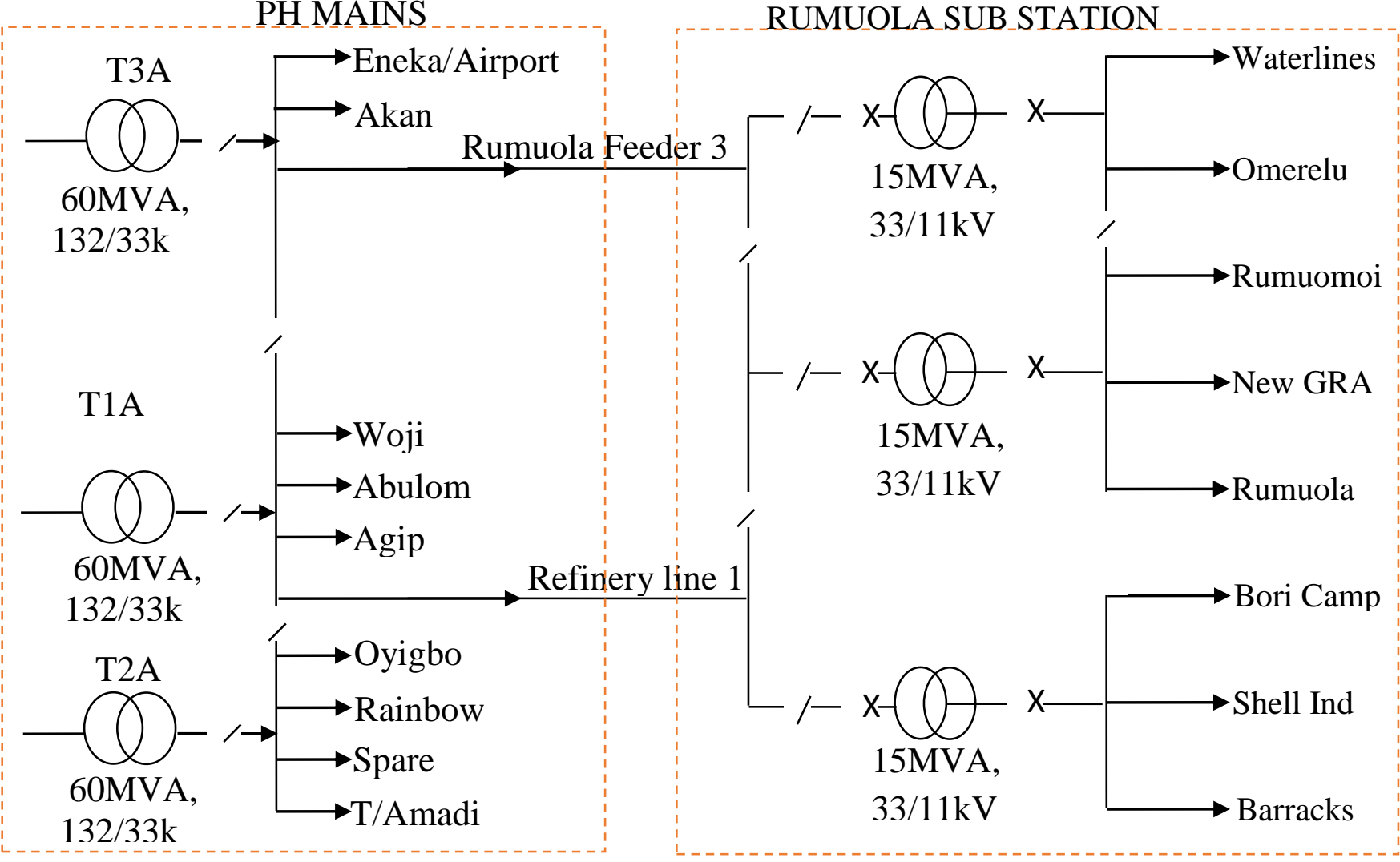

Figure 1: Single line diagram of Rumuola Injection Station (PHEDC, Port Harcourt)

Table 1: Feeder data (PHEDC, Port Harcourt)

\begin{tabular}{llccc}
\hline S/N & & $\begin{array}{c}\text { Nominal } \\
\text { Voltage } \\
\text { level }(\mathrm{kv})\end{array}$ & $\begin{array}{c}\text { Route } \\
\text { length } \\
(\mathrm{km})\end{array}$ & $\begin{array}{c}\text { Average } \\
\text { load (mw) }\end{array}$ \\
\hline \multicolumn{5}{c}{ Sources } \\
\hline 1 & Refinery 2 & 33 & 7.65 & 16 \\
2 & Feeder 3 & 33 & 19.85 & 12 \\
\hline \multicolumn{5}{c}{ Feeders } \\
\hline 1 & New GRA & 11 & 9 & 4.5 \\
2 & Rumuomoi & 11 & 11.5 & 4.6 \\
3 & Barracks & 11 & 9.3 & 4 \\
4 & Bori Camp & 11 & 12.25 & 5 \\
5 & Shell Industrial & 11 & 8.85 & 4.5 \\
6 & Rumuola & 11 & 4.6 & 5.5 \\
7 & Omerelu & 11 & 3.05 & 2.2 \\
8 & Waterlines & 11 & 15.85 & 5.5 \\
\hline
\end{tabular}

\subsection{Dynamic Voltage Restorer}

The custom power device adopted for the study is shown in figures 2 and 3 . DVR is a series compensator composed of converter, filter, storage device (in this case a battery) and coupling series transformer. The converter converts the ac source voltage into dc voltage which charges the energy storage device. The converter, also controlled by gate turn off (GTO) thyristor semiconductor in a pulse width modulation (PWM) structure, reconverts the dc into ac voltage in the event of power quality disturbances.

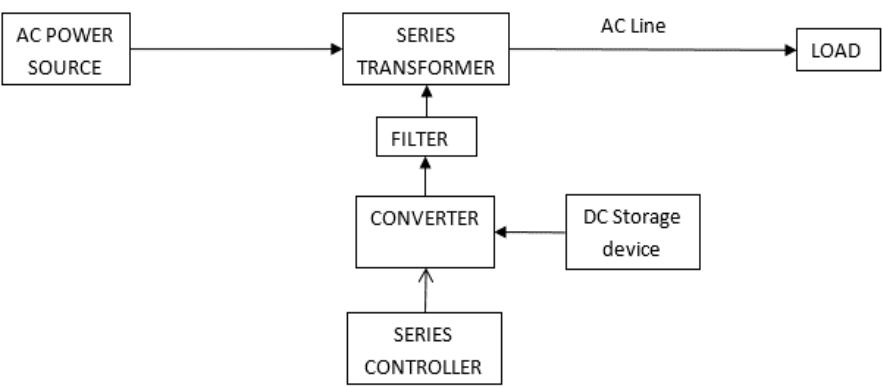

Figure 2: Block diagram of DVR System

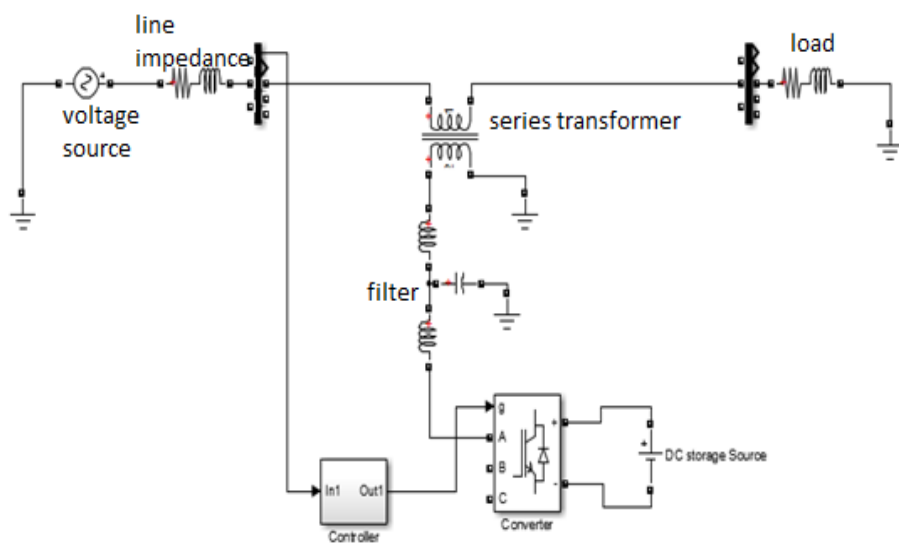

Figure 3: Single line Diagram of DVR system 
The ac output of the converter is filtered to reproduce clean voltage waveforms that are injected into the power system through a coupling series transformer. The variables which allow the control of the real and reactive power exchange are the amplitude and phase angle of the injected voltage. When a power quality problem occurs, the nominal voltage is compared with the voltage sag and the different is computed. In order to maintain load supply voltage, the battery discharges, and voltage is injected by the DVR system [13].

\subsection{Controller Modeling}

Controller modeling requires modeling proportional controller and unit amplitude template generator. The Proportional Integral controller equation is as given in equation (1) [15]

$$
\eta=\left(K_{p}+\frac{1}{S} K_{i}\right) E_{r}
$$

$E_{r}$ is the error signal defined as

$$
\mathrm{E}_{\mathrm{r}}=\left(\mathrm{V}_{\mathrm{ref}}-\mathrm{V}_{\mathrm{m}}\right)
$$

In (2), $V_{\text {ref }}$ is the require load peak voltage, $V_{m}$ is the measured peak source voltage while $K_{i}$ and $K_{p}$ are constants determined from the following equations [16]:

$$
\mathrm{K}_{\mathrm{p}} \leq \frac{\mathrm{V}_{\mathrm{dc}}}{\mathrm{I}_{\mathrm{S}} \mathrm{L}_{\mathrm{S}}}
$$

and

$$
\mathrm{K}_{\mathrm{i}} \leq\left(\frac{\mathrm{K}_{\mathrm{p}} \cos \theta}{\mathrm{I}_{\mathrm{S}}}-2 \mathrm{R}_{\mathrm{s}} \mathrm{K}_{\mathrm{p}}\right) \frac{1}{\mathrm{~L}_{\mathrm{S}}}
$$

In (3), $I_{s}, V, L_{s}$ and Rs are source current, voltage, inductance and resistance respectively, $\mathrm{V}_{\mathrm{dc}}$ is the voltage sag level to be compensated, C is the DVR filter capacitance and $\cos \theta$ is the power factor .

The Simulink model of the voltage controller is shown in Figure 4.

To convert the output of the PI controller to alternating signal having an angle in radian, $\eta$ is multiplied by a gain of 0.017 and added to $314.16 \mathrm{t}$ as given in equation (5) and shown in figure $4 \mathrm{~b}$ and fed into the unit amplitude generator [17].

$$
V_{d}=314.16 t+0.0170 u t
$$

Where $t$ is time

\section{7 Unit amplitude template generator}

Unit amplitude template generator shown in figure 5 generates the reference signals. The unit vector templates equations are given as [11].

$\mathrm{U}_{\mathrm{a}}=\sin \left(\mathrm{V}_{\mathrm{d}}\right) ; \mathrm{U}_{\mathrm{b}}=\sin \left(\mathrm{V}_{\mathrm{d}}-\mathrm{C}\right), \mathrm{U}_{\mathrm{c}}=\sin \left(\mathrm{V}_{\mathrm{d}}+\mathrm{C}\right)$

$\mathrm{C}=2.0944$

Reference voltage is got by multiplying equations (6) with unity amplitude. The output RefVolt is applied to pulse width modulator to generate the pulses for the converter.

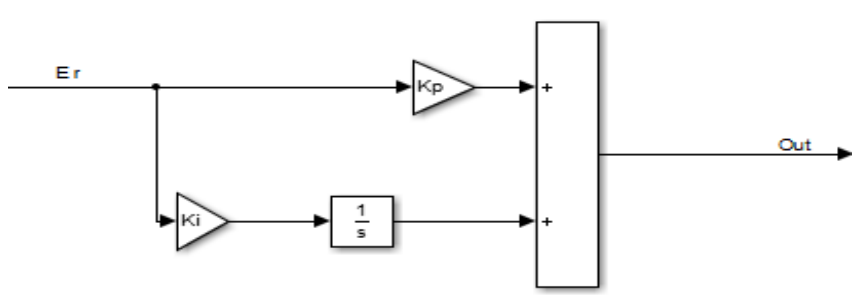

Figure 4a: Proportional integral controller

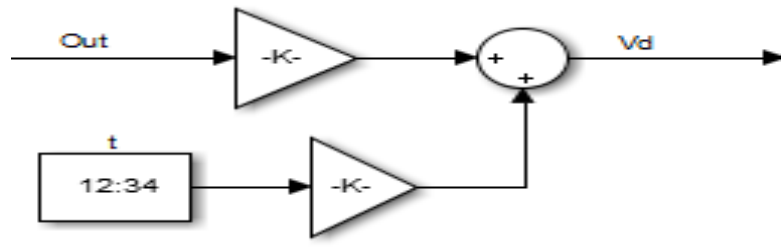

Figure 4b: PI output converter

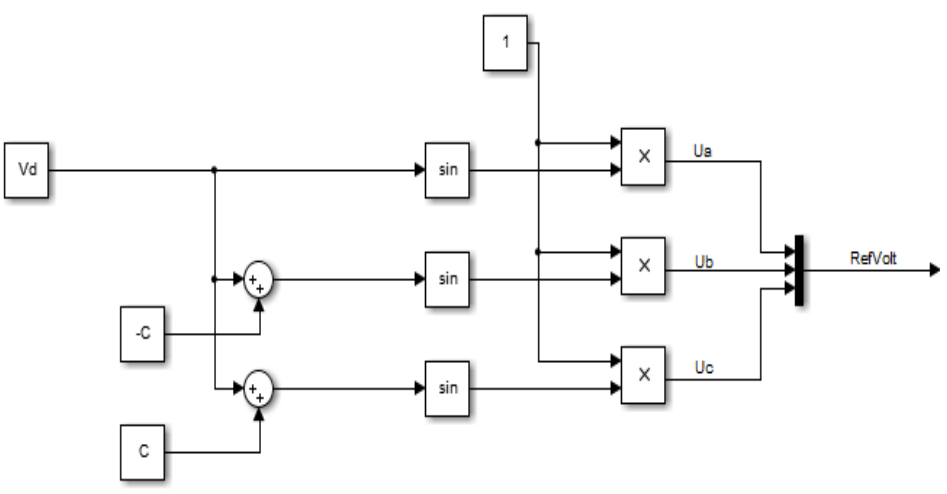

Figure 5: Unit amplitude template generator

\section{MODELING OF ANN BASED CONTROLLER}

To develop the ANN controller, the controller model shown in figure 6 was installed in the DVR system and simulated with samples of hourly voltage log. Inputs to the PI controller and outputs of PI output converter, and input/output of unit amplitude template generator were recorded and used to train ANNs. The trained ANN for PI controller and PI output converter has one input, two hidden and one output layers while that for the unit amplitude template generator has four input, two hidden and three output layers. After the trainings, the ANN blocks were generated by the command gensim(network) and incorporated to replace the PI controller and PI output converter, and unit amplitude template generator. The ANN controller model applied to control DVR is shown in figure 7 [17].

\section{SIMULATION}

The model for testing the performance of DVR is shown in figure 8. The nominal voltages of sources and eight feeders with average loads are shown in table 1. The station operates on load shedding and as such, not all feeders are closed at the same time. In this test model, Omerelu and Waterlines feeders (supplied from Rumuola Feeder 3), Rumuola, Shell Industrial and 
Barracks feeders (supplied from Refinery line 1) are closed, with average load of $10.8 \mathrm{MW}$ on Rumuola Feeder 3 and 14.4 MW on Refinery line 1, giving a total of
25.2MW at a power factor of 0.8 . The average load is calculated based on a loading structure carried out by the sub-station operators.

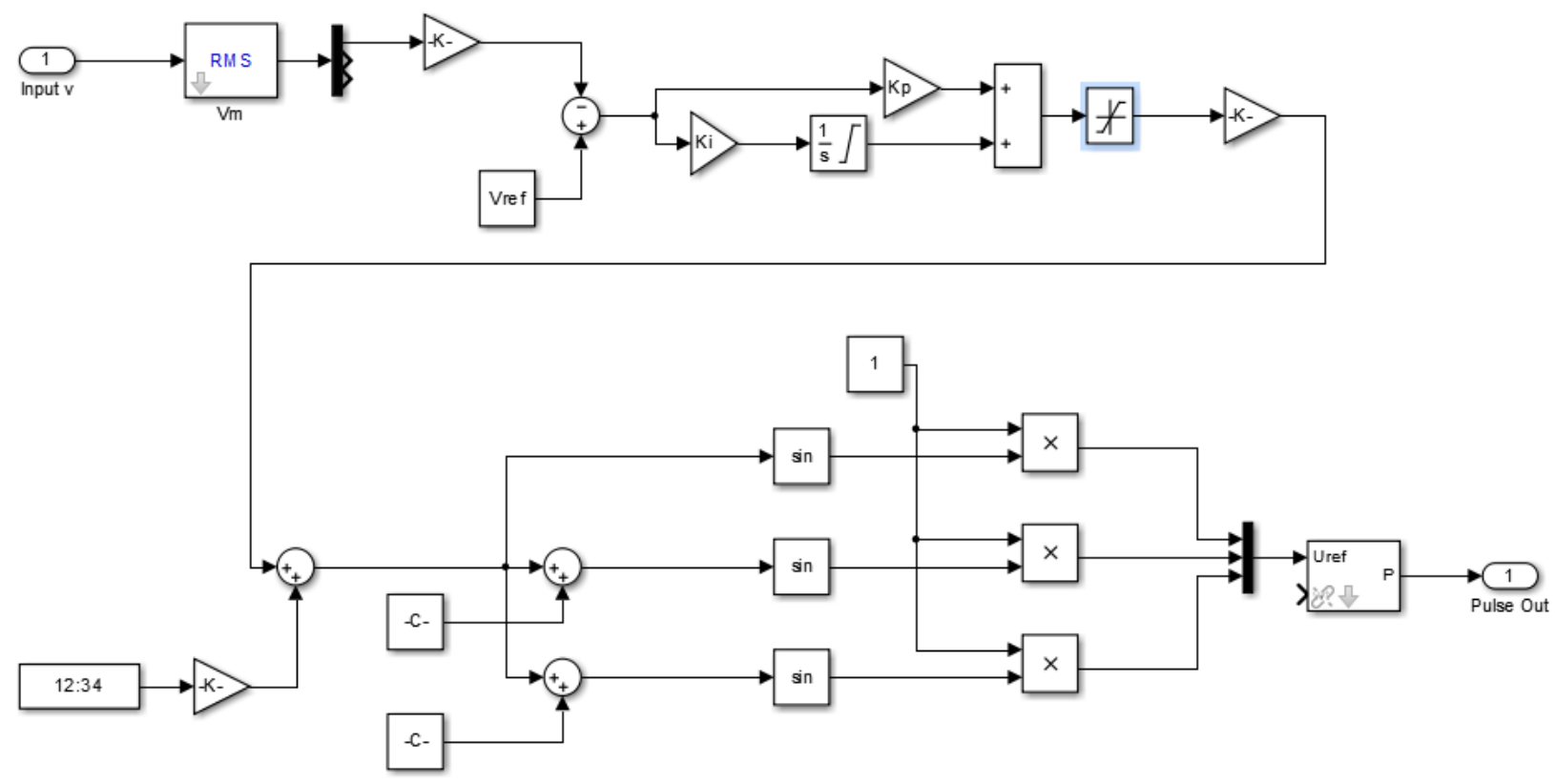

Figure 6: PI controller base model

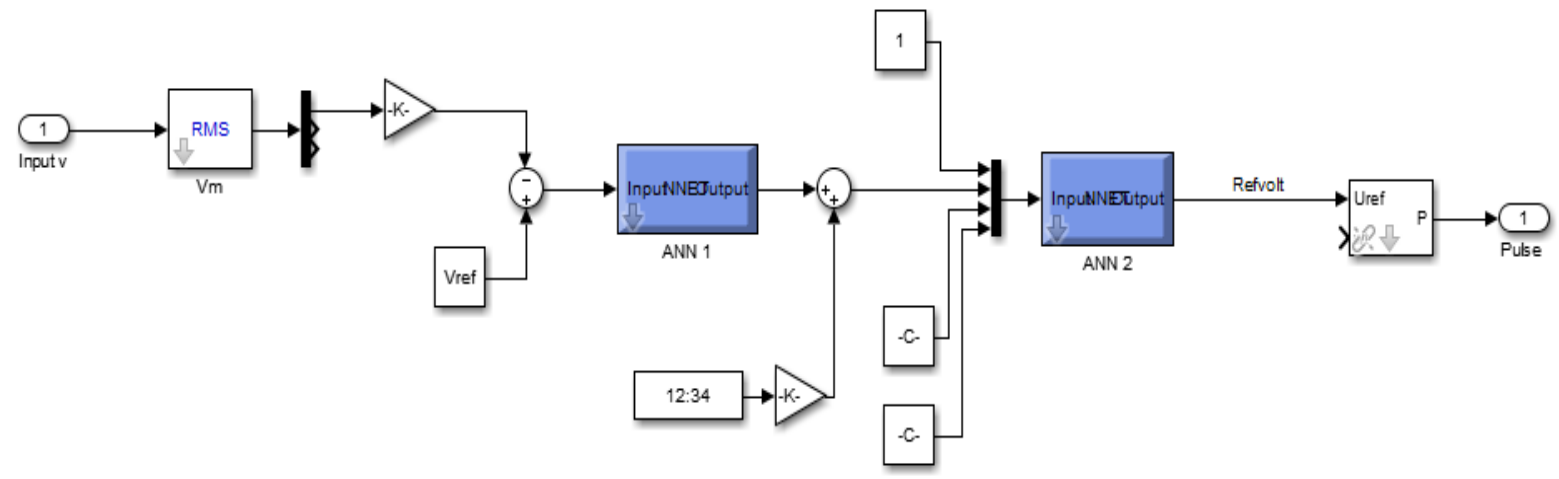

Figure 7: Proposed ANN based controller

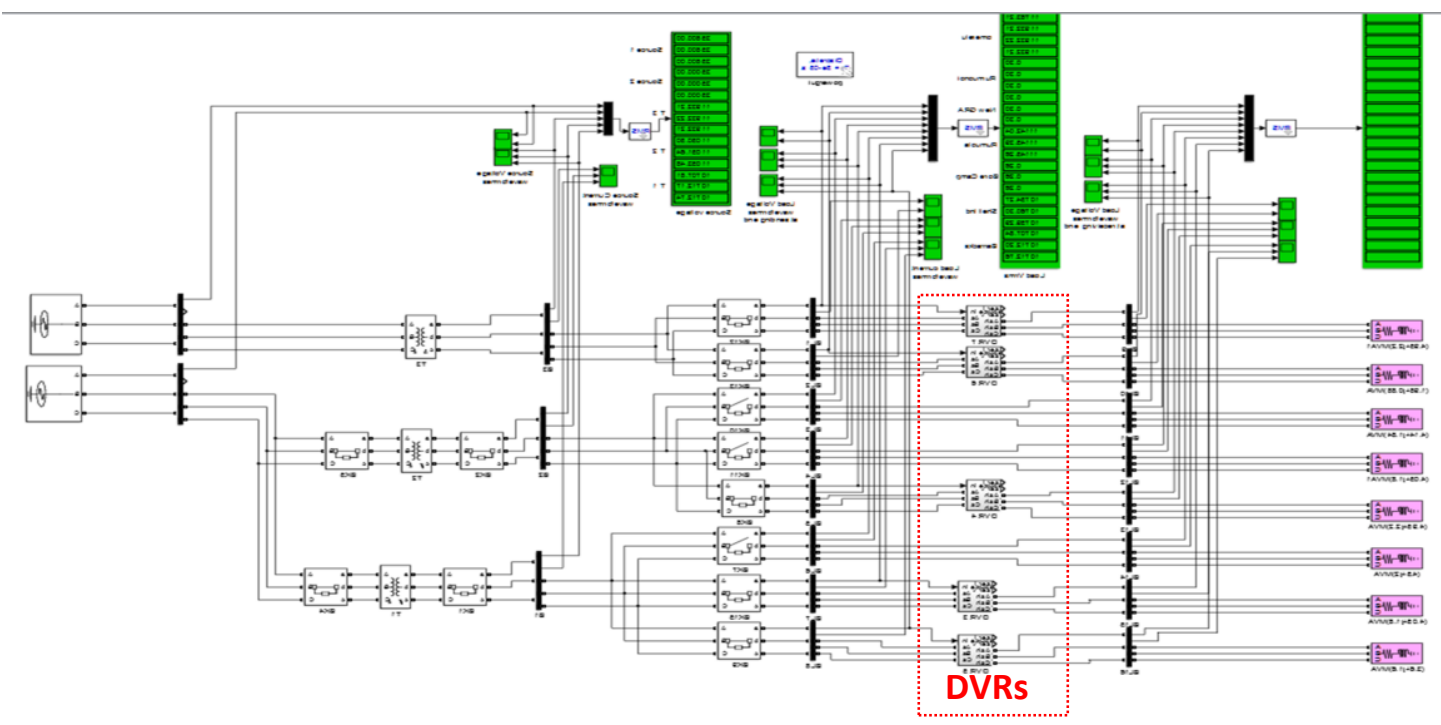

Figure 8: Simulation model with DVR 
Table 2: System loads and voltages

\begin{tabular}{llcc}
\hline S/N & & $\begin{array}{c}\text { Voltage Level } \\
(\mathrm{kV})\end{array}$ & $\begin{array}{c}\text { Average Load } \\
(\mathrm{MVA})\end{array}$ \\
\hline \multicolumn{3}{c}{ Sources } \\
\hline 2 & Refinery line 1 & 33 & $14.4+\mathrm{j} 6.4$ \\
& Rumuola & 33 & $10.8+\mathrm{j} 4.8$ \\
\hline & Feeder 3 & Feeders & \\
\hline 1 & Waterlines & 11 & $4.95+\mathrm{j} 2.2$ \\
3 & Omerelu & 11 & $1.98+\mathrm{j} 0.88$ \\
4 & Rumuola & 11 & $4.95+\mathrm{j} 2.2$ \\
5 & Shell Industrial & 11 & $4.05+\mathrm{j} 1.8$ \\
\hline
\end{tabular}

Table 2 gives the nominal voltage of sources and selected feeders. The feeders are selected in order not to exceed the maximum capacity of the sources. Simulations were done with and without DVR on Omerelu, Waterlines,
Rumuola, Shell Industrial and Barracks feeders under prevailing voltage conditions in the station.

\section{POWER QUALITY ASSESSMENT OF RUMUOLA DISTRIBUTION SYSTEM}

Samples of hourly voltage log documented over a period of six months at the Injection station were grouped for simulation purpose into three categories; minimum, average and maximum voltages as shown in table 3 . As seen in the table, the prevalent power quality problems are under-voltage and over-voltage with values less than $10.5 \mathrm{kV}$ and above $11.5 \mathrm{kV}$ respectively. To check for distortions, the sample voltages were simulated without DVR in separate simulations. The observed waveforms were sinusoidal, showing that there were no significant distortions in voltage waveforms at the station. Figure 9 shows the signal waveforms for minimum voltage (this is similar to the waveforms of the other two categories except in amplitude).

Table 3: Feeder Sample Voltages

\begin{tabular}{|c|c|c|c|c|c|c|c|c|c|}
\hline \multirow{3}{*}{ FEEDERS } & \multirow{3}{*}{ PHASE } & \multicolumn{6}{|c|}{ SAMPLES OF HOURLY VOLTAGE (kV) } & \multirow{2}{*}{\multicolumn{2}{|c|}{ Norminal Voltage }} \\
\hline & & \multicolumn{2}{|c|}{ Minimum Voltage } & \multicolumn{2}{|c|}{ Average Voltage } & \multicolumn{2}{|c|}{ Maximum Voltage } & & \\
\hline & & 33kV side & 11kVside & 33kV side & 11kVside & 33kV side & 11kVside & 33kVside & $11 \mathrm{kVside}$ \\
\hline & Phase $\mathrm{A}$ & 28.5 & 9.4 & 31.5 & 10.5 & 35.5 & 11.8 & 33 & 11 \\
\hline \multirow[t]{3}{*}{ Waterlines } & Phase B & 28.5 & 9.4 & 31.5 & 10.5 & 35.5 & 11.8 & 33 & 11 \\
\hline & Phase C & 28.5 & 9.4 & 31.5 & 10.5 & 35.5 & 11.8 & 33 & 11 \\
\hline & Phase A & 28.5 & 9.4 & 31.5 & 10.5 & 35.5 & 11.8 & 33 & 11 \\
\hline \multirow[t]{3}{*}{ Omerelu } & Phase B & 28.5 & 9.4 & 31.5 & 10.5 & 35.5 & 11.8 & 33 & 11 \\
\hline & Phase C & 28.5 & 9.4 & 31.5 & 10.5 & 35.5 & 11.8 & 33 & 11 \\
\hline & Phase A & 28.5 & 9.4 & 31.5 & 10.5 & 35.5 & 11.8 & 33 & 11 \\
\hline \multirow[t]{3}{*}{ Rumuola } & Phase B & 28.5 & 9.4 & 31.5 & 10.5 & 35.5 & 11.8 & 33 & 11 \\
\hline & Phase C & 28.5 & 9.4 & 31.5 & 10.5 & 35.5 & 11.8 & 33 & 11 \\
\hline & Phase $A$ & 28.5 & 9.4 & 31.5 & 10.5 & 35.5 & 11.8 & 33 & 11 \\
\hline \multirow[t]{3}{*}{ Shell Industrial } & Phase B & 28.5 & 9.4 & 31.5 & 10.5 & 35.5 & 11.8 & 33 & 11 \\
\hline & Phase C & 28.5 & 9.4 & 31.5 & 10.5 & 35.5 & 11.8 & 33 & 11 \\
\hline & Phase $A$ & 28.5 & 9.4 & 31.5 & 10.5 & 35.5 & 11.8 & 33 & 11 \\
\hline \multirow[t]{2}{*}{ Barracks } & Phase B & 28.5 & 9.4 & 31.5 & 10.5 & 35.5 & 11.8 & 33 & 11 \\
\hline & Phase C & 28.5 & 9.4 & 31.5 & 10.5 & 35.5 & 11.8 & 33 & 11 \\
\hline
\end{tabular}

Figure 9:Feeders'sample voltage signal waveforms without DVR (minimum voltage) 
Table 4: Feeder Voltages with DVR installed on the feeders

\begin{tabular}{|c|c|c|c|c|c|}
\hline \multirow[b]{2}{*}{ FEEDERS } & \multicolumn{4}{|c|}{ COMPENSATED SAMPLES OF HOURLY VOLTAGE FOR 11kV SIDE } & \multirow[b]{2}{*}{ Nominal Voltage $(\mathrm{kV})$} \\
\hline & Phase & $\begin{array}{l}\text { Minimum } \\
\text { Voltage }\end{array}$ & Average Voltage & $\begin{array}{c}\text { Maximum } \\
\text { Voltage }\end{array}$ & \\
\hline \multirow{3}{*}{ Waterlines } & Phase A & 10.9 & 11.0 & 11.0 & 11.0 \\
\hline & Phase B & 10.9 & 11.0 & 11.0 & 11.0 \\
\hline & Phase C & 10.9 & 11.0 & 11.0 & 11.0 \\
\hline \multirow{3}{*}{ Omerelu } & Phase A & 10.9 & 11.0 & 11.0 & 11.0 \\
\hline & Phase B & 10.9 & 11.0 & 11.0 & 11.0 \\
\hline & Phase C & 10.9 & 11.0 & 11.0 & 11.0 \\
\hline \multirow{3}{*}{ Rumuola } & Phase A & 10.9 & 11.0 & 11.0 & 11.0 \\
\hline & Phase B & 10.9 & 11.0 & 11.0 & 11.0 \\
\hline & Phase C & 10.9 & 11.0 & 11.0 & 11.0 \\
\hline \multirow{3}{*}{ Shell Industrial } & Phase A & 10.9 & 11.0 & 11.0 & 11.0 \\
\hline & Phase B & 10.9 & 11.0 & 11.0 & 11.0 \\
\hline & Phase C & 10.9 & 11.0 & 11.0 & 11.0 \\
\hline \multirow{3}{*}{ Barracks } & Phase A & 10.9 & 11.0 & 11.0 & 11.0 \\
\hline & Phase B & 10.9 & 11.0 & 11.0 & 11.0 \\
\hline & Phase C & 10.9 & 11.0 & 11.0 & 11.0 \\
\hline
\end{tabular}

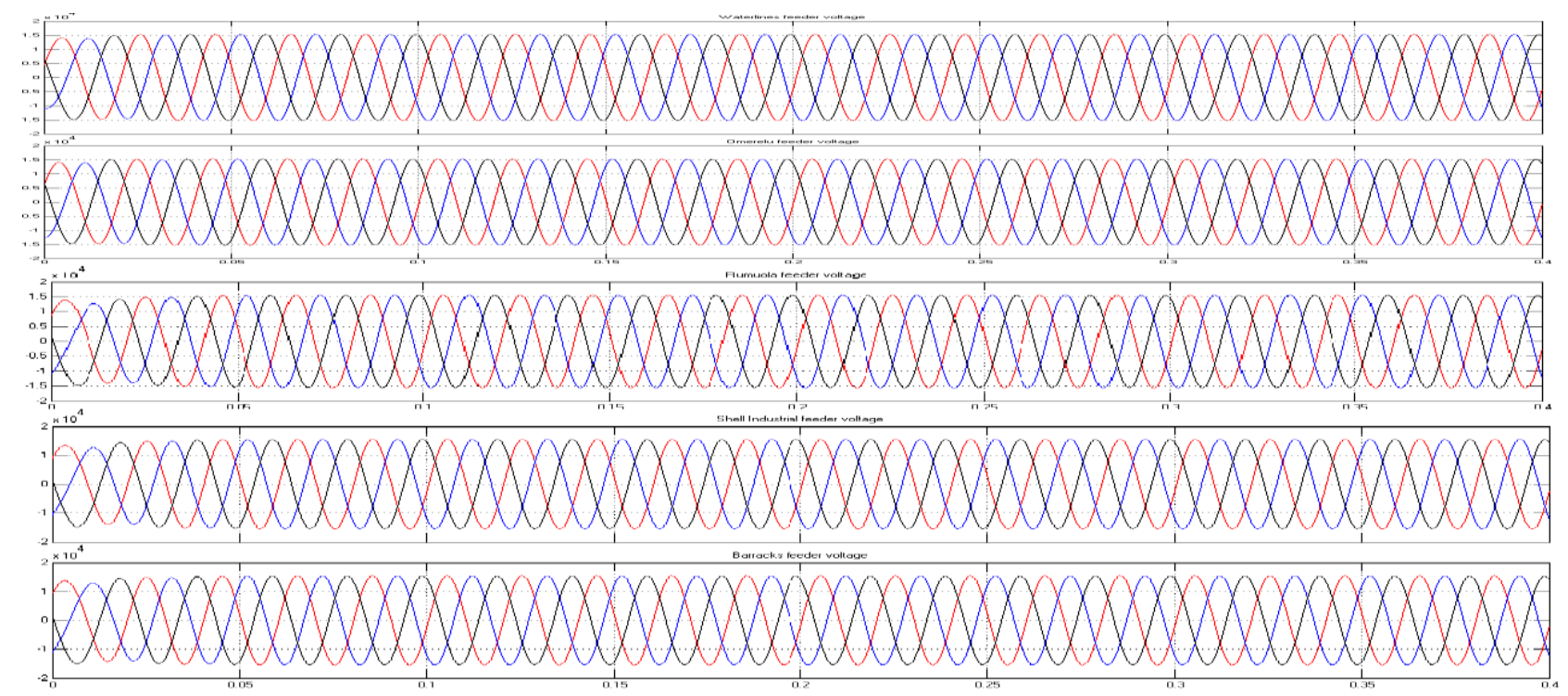

Figure 10: Feeders' voltage signal waveforms with DVR (minimum voltage)

\section{OVER-VOLTAGE AND UNDER-VOLTAGE} COMPENSATION IN RUMUOLA DISTRIBUTION NETWORK

With the installation of DVR at the feeders as shown in figure 8, remarkable results are obtained at the feeders. Table 4 gives the voltage levels of feeders with DVR and figure 10 shows the voltage waveforms for minimum voltage with DVR.

\section{CONCLUSION AND RECOMMENDATION}

This work investigated the application of ANN controller base DVR in Rumuola Distribution System Network for under-voltage and over-voltage mitigation. The software adopted for modeling and analysis was matlab/simulink, and the ANN controller was trained with LevenbergMarquardt algorithm. Unit amplitude template generator which was replaced with ANN was employed to generate the reference signal which was applied to pulse width modulator for pulse production for the converter. A particular loading structure of the injection station having five feeders closed was adopted for simulation. The impact of DVR was studied with samples of hourly voltage log for all the selected feeders. Simulation results showed that DVR could be employed to mitigate undervoltage and over-voltage problems in the sub-station network.

The authors recommend the application of DVR in the sub-station and that further investigation should be carried out in the design of renewable power source that can enhance recharging of the dc storage device. 


\section{ACKNOWLEDGEMENT}

The authors wish to acknowledge the support of Port Harcourt Electricity Distribution Company, for providing necessary data used for the study.

\section{REFERENCES}

[1] Sankaran, C. (2002). Power Quality, CRC PRESS Boca Raton London New York Washington, D.C., 2002.

[2] Zahir, J. P. Computational Techniques for Power Quality Data Monitoring and Management, Ph.D Thesis, Australia University, 2011.

[3] Joseph, S. 'The Seven Types of Power Problems', Schneider Electric-Data Center Science Center, 2011

[4] Ogunyemi, J., Fakolujo, A. and Adejumobi, I. A. "Power Quality Assessment in Nigerian Distribution Network" EIE's 2nd International Conference. Comp., Energy, Net., Robotics and Telecom, 2012, pp.103-111

[5] Mohamed, I. S. A. and Suliman, M. E. "Power Quality Evaluation of Electrical Distribution Networks", International Journal of Electrical, Computer, Electronics and Communication Engineering Vol. 8, Number 10, 2014, pp.1499-1503

[6] Lokendra, P. S., Ravinder, S. B. and Dinesh, K. J. "Survey related to Power Quality Issues in Indian Electricity Market", International Journal of Electrical, and Computer Engineering 3(1), 2014, pp.37-47.

[7] Christian, R., Stefan, H. and Jürgen, B. "Power Quality and Stability Issues in Modern Distribution Grids: Identification and Mitigation", CIRED Workshop - Rome, June 11-12, 2014, pp.1-5.

[8] Port Harcourt Electricity Distribution Company, Garden City Central Integrated Business Centre, Accessed June 12, 2015

[9] Irfan, I. M., Patil, D. R. and Isak, I. M. "Reactive Power Compensation and Harmonic Mitigation of Distribution System using SAPF Compensator", International Journal of Engineering Science and
Innovative Technology Vol. 2, Issue 3, 2013, pp.495-502

[10] Onohaebi, S. O. and Omorogiuwa, E. "Prospects of Custom Power Devices in Improving Reliability of Distribution Networks in Nigeria" International Journal of Electronics Communication and Computer Engineering, Vol. 5, Issue 5, 2015, pp.1120-1123.

[11] Vinita, V., Rintu, K. and Manoj, K. "Improvement of Power Quality by UPQC Using Different Intelligent Controls: A Literature Review, International Journal of Recent Technology and Engineering, Vol.2, Issue 1, 2013, pp.173-177.

[12] Sundarabalan C. K. and Selvi K. "Power Quality Enhancement in Power Distribution system using Artificial intelligence based Dynamic Voltage Restorer", International Journal on Electrical Engineering and Informatics Vol. 5, Number 4, 2013, pp.433-446.

[13] Shairul, W. W. and Alias, M. Y. "Voltage Sag and Mitigation Using Dynamic Voltage Restorer (DVR) System", Elektrika, Malaysia 8(2), 2006, pp. 32-37

[14] Raunak. J., Kapil, P. and Pradeep, A. "Reducing the Voltage Sag and Swell Problem in Distribution System Using Dynamic Voltage Restorer with PI Controller", International Journal of Soft Computing and Engineering, Vol.3, Issue 6, 2014, pp.193-202.

[15] Mohankumar, G. B. and Manoharan, S. "Performance Analysis Of Multi Converter Unified Power Quality Conditioner Using PI Controller", Australian Journal of Basic and Applied Sciences 7(9), 2013, pp. 331340

[16] Moleykutty, G. "Artificial Intelligence Based ThreePhase Unified Power Quality Conditioner" Journal of Computer Science 3 (7), 2007, pp. 465-477.

[17] Offor, G. O. Power Quality Improvement in Distribution Network Using Artificial Neural Network: A Case Study, M. Eng. Dissertation, Department of Electrical and Electronics Engineering, University of Port Harcourt, Nigeria, 2016 (Unpublished) 